\section{Representation of Industry in Introductory Biology Textbooks: A Missed Opportunity to Advance STEM Learning}

Sharotka M. Simon, ${ }^{+\neq}$Helen Meldrum, ${ }^{*}$ Eric Ndung' ${ }^{\prime}{ }^{\dagger}$ and Fred D. Ledley ${ }^{\dagger \neq \$ *}$

${ }^{\dagger}$ Center for Integration of Science and Industry, "Department of Natural \& Applied Sciences, and

s.Department of Management, Bentley University, Waltham, MA 02452

\begin{abstract}
The majority of students who enroll in undergraduate biology courses will eventually be employed in non-STEM (science, technology, engineering, and mathematics) business occupations. This work explores how representations of industry in undergraduate biology textbooks could impact STEM learning for these students and their ability to apply this learning in their chosen work. We used text analysis to identify passages with references to industry in 29 textbooks. Each passage was categorized for relevance to health or environment, for implied positive or negative connotations, and for descriptions of synergy or conflict between science and industry. We found few passages describing applications of STEM learning in non-STEM business occupations and a paucity of content to support context-based learning for students aiming at business careers. A significant number of passages embodied negative connotations regarding industry. Notable passages highlighted irregular or fraudulent business practices or included simplistic caricatures of business practice. We discuss how the representation of industry in these textbooks may impact student engagement, context-based learning, the ability of students to critically apply STEM learning in industry or business occupations, and heuristics that guide intuitive perceptions about the intersection between science and industry.
\end{abstract}

\section{INTRODUCTION}

As the body politic increasingly views the mission and value of a college education as preparing students for employment (National Research Council [NRC], 2002, 2010; National Academy of Sciences, National Academy of Engineering, and Institute of Medicine [NAS et al.], 2005; Taylor et al., 2011; President's Council of Advisors on Science and Technology, 2012), it is essential to recognize that the majority of students who enroll in "introductory" undergraduate science courses will eventually be employed in non-scientific occupations, primarily business occupations. This is true whether or not they complete a science and engineering (S\&E) major (U.S. Census Bureau, 2014). In this context, the research presented here considers how textbooks for introductory biology represent the relationship between science and industry, and how this representation might impact student learning.

A series of initiatives since 2000 has focused on reforming science education to meet the workforce needs of the technology-driven, innovation economy (NRC, 2003; Ganter and Barker, 2004; NAS et al., 2005; Connelly and Sharp, 2009; American Association for the Advancement of Science [AAAS], 2011; Holdren et al., 2013; Alper, 2016). Each of these reports focuses primarily on ensuring there is an adequate pipeline of S\&E majors to work in science, technology, engineering, and mathematics (STEM) occupations. The majority of undergraduate students who enroll in first-year S\&E courses, however, will eventually be employed in non-STEM occupations (U.S. Census Bureau, 2014). Data from the United States Census Bureau (2012) show that only
James Hewlett, Monitoring Editor Submitted Mar 31, 2017; Revised Sep 4, 2018; Accepted Sep 17, 2018

CBE Life Sci Educ December 1, 2018 17:ar61 DOI:10.1187/cbe.17-03-0057

*Address correspondence to: Fred D. Ledley (fledley@bentley.edu).

○ 2018 S. M. Simon et al. CBE-Life Sciences Education @ 2018 The American Society for Cell Biology. This article is distributed by The American Society for Cell Biology under license from the author(s). It is available to the public under an Attribution-Noncommercial-Share Alike 3.0 Unported Creative Commons License (http://creativecommons.org/licenses/ by-nc-sa/3.0).

"ASCB®" and "The American Society for Cell Biology $® "$ are registered trademarks of The American Society for Cell Biology. 
$35.6 \%$ of students complete their first bachelor's degree in S\&E fields. Business is the most prevalent major in U.S. higher education, representing $21.9 \%$ of all college majors and $34 \%$ of those outside the S\&E discipline (U.S. Census Bureau, 2012). Many non-S\&E majors enroll in science courses to fulfill general education requirements in "natural science," which are required at the majority of American colleges and universities (Brint et al., 2009).

Data also demonstrate that only a third of students who complete non-S\&E majors go on to pursue STEM occupations (Landivar, 2013). The U.S. Census Bureau's American Community Survey (2011) shows that only $26 \%$ of students with S\&E degrees are employed in a "STEM occupation," and only $37 \%$ are employed in "STEM-related occupations," a categorization that also includes healthcare (Landivar, 2013). Of the $63 \%$ employed in "alternative" non-STEM occupations, most are employed in business roles such as managers, executives, accountants, or analysts (U.S. Census Bureau, 2011). As for graduate degree holders, more than $50 \%$ of students completing professional science master's programs go on to employment in business roles in management, regulatory affairs, public policy, communications, marketing/sales, or intellectual property (Allum, 2013), and recent studies of graduates from S\&E doctoral programs show increasing interest in nonacademic or alternative careers as training progresses (Fuhrmann et al., 2011; Gibbs et al., 2014).

Focusing specifically on the life sciences, majors in "biological, agricultural, and environmental sciences" represent only $6.6 \%$ of all first college degrees (U.S. Census Bureau, 2014). Of these graduates, only $15 \%$ work in STEM occupations, with another 30\% working in healthcare and 10\% in education (U.S. Census Bureau, 2014). Of the $37 \%$ who work in other occupations, many are employed in business roles (U.S. Census Bureau, 2014). Moreover, $\sim 30 \%$ of individuals with doctorates in biology-related disciplines will work in the biopharmaceutical industry, many in non-STEM related business occupations (National Institutes of Health, 2012). These data show that the majority of students who enroll in "introductory" biology classes, whether for majors or nonmajors, will ultimately come to be employed in non-STEM occupations, mainly in business roles.

The premise of this study is that, for students who will find careers in business occupations, STEM learning may be impacted by the way curricular materials represent the relationship between science and industry. We are interested in whether curricular materials describe opportunities for applying STEM learning in business occupations, incorporate content to support context-dependent learning, and promote a critical, constructive appreciation of how science can contribute to industry and business occupations.

This work looks explicitly at the representation of industry in textbooks developed for introductory, undergraduate biology courses. We used text analysis to identify passages that included terms related to industry and examined these passages to ask three research questions:

First, do these texts describe opportunities and examples for the application of STEM learning in non-STEM occupations? Because the majority of students in an introductory biology class will work in non-STEM occupations in industry, we asked whether the texts provide explicit examples for how the course material may contribute to these occupations. Second, do the texts provide content for context-based learning? Scholarship on teaching and learning has demonstrated that STEM learning can be enhanced by connecting scientific principles to familiar contexts (Brown et al., 1989; NRC, 1999), and that recognizing the relevance of science to careers promotes both achievement and motivation to learn (Glynn et al., 2007). Given that the focus of most students is on business careers in industry, we asked whether the scientific concepts were presented as solutions to issues of interest to industry.

Third, do the texts provide constructive heuristic models for the application of STEM learning and in industry? This question was prompted by the sometimes contentious relationship between science and industry, where science seeds the pipeline for product innovation, but the involvement of corporations in scientific research or policy is often portrayed as a "conflict of interest." We are also interested in how the representation of industry could impact the student's intuitive impressions about the intersection of science and industry.

A large body of research on cognition demonstrates that people predictably formulate initial judgments on quick intuitive impressions (De Neys and Bonnefon, 2013). This type of thinking uses "heuristics," which are simple principles or examples acquired through evolution or learning (Tversky and Kahneman, 1974). Heuristics simplify and speed cognitive processing by providing shortcuts to classify observations and situations (Shah and Oppenheimer, 2008). This substitution is thought of as taking place in the fast, automatic, or intuitive judgment system, rather than the slower, more self-aware, reflective, or critical thinking system. Of particular significance is research showing that intuitive reasoning can create persistent cognitive bias and errors (Haselton et al., 2005). Individuals are often naïve about the influence of this habit of mind, believing they can formulate a conscious understanding of the world that provides a complete and accurate representation (Kahneman, 2011). Daniel Kahneman (2003), who won the Nobel Prize for pioneering this area of research, summarized it thus: "People are not accustomed to thinking hard, and are often content to trust a plausible judgment that quickly comes to mind" (p. 1450). While one of the often-stated goals of including STEM courses in a general education curriculum is to promote critical, scientific thinking, it is also necessary to consider the potential impact of curriculum on intuitive reasoning.

We found that these textbooks do not provide explicit examples of how science can be applied in non-STEM occupations and offer few examples of scientific content in the context of real-world, industrial applications. Moreover, we observed that a significant number of references to industry embodied negative connotations. These findings are discussed in light of evidence that science learning can be enhanced by providing instruction in context that engages students, as well as evidence from cognitive science describing the essential roles of both intuitive and critical thinking in applying concepts to practice.

\section{METHODS}

We used a mixed-methods approach, first to identify mentions of business and industry within biology textbooks, next to code 
these mentions for passage content, and finally to quantify passages and codes for trend analysis.

\section{Textbooks}

Textbooks listed as general biology or human biology for majors or nonmajors were identified on the Brooks/Cole Cengage Learning, Bartlett Learning, Benjamin Cummings Pearson Education, McGraw-Hill, W.H. Freeman, and Wiley websites, as described previously (Wernick et al. , 2014). Twenty-nine books were examined (Supplemental Table 1). We did not examine laboratory manuals or other supplemental material that might be provided with the textbooks.

Bowker's (now Nielsen) PubTrack database of textbook adoption in introductory biology courses was purchased from the publisher. As described in Wernick et al. (2014), these texts, or editions of these texts, were used in 29,000 course sections enrolling 1.4 million students in 2005 . This represented $47 \%$ of all course sections and $50 \%$ of students enrolled in undergraduate biology. Significantly, no other texts in PubTrack were used in more than $1 \%$ of course sections or by more than $2 \%$ of students.

Each bound textbook was scanned to portable document format (PDF) and translated to text using the optical character recognition function of Adobe Acrobat. This process translates the body of the text, references, figure legends, and most sidebars, but may not extract text from figures.

\section{NVivo search}

We used the NVivo text search function to identify search terms in each textbook and to extract passages containing that term. Passages were extracted using NVivo's "broad context."

Passages referring to careers were identified by searching the text for a lexicon of terms including "career," "employment," "hiring," "occupation," and "profession."

Passages with industry-related terms were identified by searching the text for a lexicon of terms including "industry," "business," "commerce," "company," "corporation," "incorporated" (Inc.), "earnings," "income," "profit," and "revenue," as well as stemmed, plural, or possessive use of these terms. A search for "non-profit/nonprofit" was conducted and analyzed separately to allow comparison between representations of nonprofit and for-profit corporate entities.

The NVivo Find Slider was adjusted to find words with the same stems as the original search terms. Each passage was assigned a unique identifying number and coded by two raters (S.M.S. and F.D.L.). Both raters have doctorate degrees in biology or medicine and experience teaching biology to undergraduate students and have also conducted research or served in executive positions in industry. Neither has contemporaneous industry associations or funding.

Coding was based on content specifically related to the search term, not to other content in the passage. If the content in the passage was insufficient to ascertain connotations associated with the search term, the passage was not coded. If the passage was identified in multiple searches using different search terms, each search each term was coded independently of the others in the same passage.

\section{Coding}

A coding guidebook was established to describe rules for coding each passage (Supplemental Table 2). The coding guidebook includes a definition of each criterion, as well as examples of content that fit, or did not fit, within each category.

A total of 147 passages were identified by searching for "Career Relevant" terms. This set was collected and analyzed separately from the "Industry Relevant" terms described later.

From a total of 2237 passages identified by searching for words in the industry-related lexicon, we extracted a random set of 200 passages for use as a training set in developing our coding guidebook (Supplemental Table 2). The coding guidebook was refined using a validation set, composed of an independent set of 200 randomly chosen passages until interrater reliability (IRR) reached greater than 90\% (see Supplemental Table 3 for details). The final coding guidebook was then used by the two independent raters to code all 2237 passages. The coding guidebook is intended to reflect the positive aspirations of both science and industry.

IRR was calculated using Cohen's kappa coefficient and is available in Supplemental Table 3. Only results of passages coded consistently by both raters are presented in Table 1 and Figure 1. Data analysis was performed using NVivo and Excel.

\section{Definitions and Classifications}

While the terms "business" and "industry" are often used interchangeably, we use the term "industry" primarily to represent economic enterprise, commonly involving for-profit corporations, but also including nonprofit organizations, for example, the "healthcare industry." We use the term "business" primarily to describe non-STEM occupations, such as management, finance, marketing, or sales, the practice of these occupations (e.g., "business practice"), or education aimed at training students for these occupations (e.g., "business discipline" or "business major"). We would note that business occupations are not exclusively associated with for-profit, commercial enterprise, as industry also employs many STEM and STEM-related workers, and nonprofit organizations also require business functions. We would also note that these terms appear in many of the textbook quotes without these delimited meanings.

Insufficient Context for Coding. Some passages recovered by NVivo were from an index, table of contents, bibliography, title, figure legend, or other fragmentary text that did not provide context for coding. These passages were excluded from all analyses and the data shown in Table 1.

Career Relevant or Career: Other Use of Term. Passages were rated as "Career Relevant" if the use of the term in the lexicon was in the context of preparing the student for a career. Such passages related either generally to application of STEM learning in any type of career, or specifically to careers in either industry or academic science. Passages were rated as "Career: Other Use of Term" if the word referred to historical or biographical information or credits or citations or was a homonym that does not relate to careers. Detailed criteria and examples are listed in the coding guidebook (Supplemental Table 2).

Industry Relevant or Industry: Other Use of Term. Many of the industry-related terms in the lexicon appeared in passages either with the anticipated meaning related to industry or 
TABLE 1. Summary statistics of passages coded as Positive Connotation and Negative Connotation ${ }^{\mathrm{a}}$

\begin{tabular}{|c|c|c|c|c|c|c|c|}
\hline \multirow[b]{2}{*}{ Search term } & \multirow{2}{*}{$\frac{\text { Industry Relevant }}{\text { No. }}$} & \multicolumn{2}{|c|}{ Positive Connotation } & \multicolumn{2}{|c|}{ Negative Connotation } & \multicolumn{2}{|c|}{ Balanced (both Positive and Negative) } \\
\hline & & No. & $\%$ & No. & $\%$ & No. & $\%$ \\
\hline All & 1358 & 268 & 20 & $492 * * *$ & 36 & 75 & 6 \\
\hline Environmental Impact & 435 & 67 & 15 & $325 * * *$ & 75 & 25 & 6 \\
\hline Business & 54 & 16 & 30 & 17 & 31 & 6 & 11 \\
\hline Commerce & 7 & 2 & 29 & 4 & 57 & 0 & 0 \\
\hline Corporate & 4 & 1 & 25 & 1 & 25 & 0 & 0 \\
\hline Corporation & 21 & 10 & 48 & 4 & 19 & 2 & 10 \\
\hline Earnings & 3 & 1 & 33 & 0 & 0 & 0 & 0 \\
\hline Income & 37 & 6 & 16 & 0 & 0 & 0 & 0 \\
\hline Incorporated & 0 & 0 & N/A & 0 & N/A & 0 & N/A \\
\hline Non-profit or Nonprofit & 30 & $22 * * *$ & 73 & 0 & 0 & 0 & 0 \\
\hline
\end{tabular}

${ }^{a}$ Numbers reported for Positive Connotation and Negative Connotation include those that are also reported for Balanced (having both Positive Connotation and Negative Connotation). Numbers determined to be significant by chi-square analysis are represented as follows: ${ }^{*} p<0.05 ; * * p<0.01 ;{ }^{* * *} p<0.001$.

business or as a homonym with a meaning related to a biological entity or process. Each passage was rated as "Industry Relevant" or "Industry: Other Use of Term" according to the coding guidebook. Passages rated as Industry: Other Use of Term were not coded for other characteristics and are not included in Table 1.

Human Impact or Environmental Impact. Passages were coded for whether the Industry Relevant term was used specifically in relation to "Health \& Human Impact" (including health, disease, nutrition, food production) or "Environmental Impact" (damage, remediation, sustainability, climate change). Passages were coded independently for Human Impact and Environmental Impact according to the coding guidebook, and could thus be classified as Human Impact, Environmental Impact, both, or neither.

Positive Connotation or Negative Connotation. Passages were coded for whether the Industry Relevant term was associated with language that implied a "Positive Connotation" or a "Negative Connotation." A Positive Connotation was one that implied a constructive human, environmental, or other intended or practical beneficial impact. A Negative Connotation implied a harmful human, environmental, or other impact. Passages were coded independently for Positive Connotation and Negative Connotation according to the coding guidebook, and could thus be classified as Positive Connotation, Negative Connotation, both (Balanced), or neither.

Synergy and Conflict. Passages were coded for whether the industry-relevant term was used to describe "Synergy" (scientific advancement of industry through R\&D, intellectual property, or launching new industries) or "Conflict" (industry interfering with the practice or public acceptance of science, or science interfering with the practice of business) between the practices of business and science. Passages were considered independently for Synergy and Conflict according to the coding guidebook and could thus be classified as Synergy, Conflict, both, or neither.

Chi-Square Analysis. Chi-square analysis was performed to determine significant differences in Positive Connotation or Negative Connotation of mentions of industry. Analysis was performed using one degree of freedom and considering Positive Connotation separately from Negative Connotation. Passages coded as having both Positive Connotation and Negative Connotation (Balanced) were represented twice in this analysis, once for Positive Connotation and once for Negative Connotation, such that codes rather than passages were analyzed. Analysis was performed for the complete data set, for relationship to either Human Impact or Environmental Impact, and for individual search terms. Results of chi-square analysis are shown in Table 1.

\section{RESULTS}

This research asks whether textbooks designed for introductory, undergraduate biology courses describe opportunities to apply this learning in industry and in business occupations, and whether they provide constructive representations of industry to facilitate the effective integration of science with industry and business practices. We report our findings of business- and industry-related terms in these textbooks, along with both raw counts and examples of passages that fit the classification scheme outlined in the coding guidebook (Supplemental Table 2).

\section{Career Relevant Passages}

We searched the 29 textbooks to identify passages with search terms related to careers and whether or not they were associated with industry. NVivo identified 147 such passages, of 
A

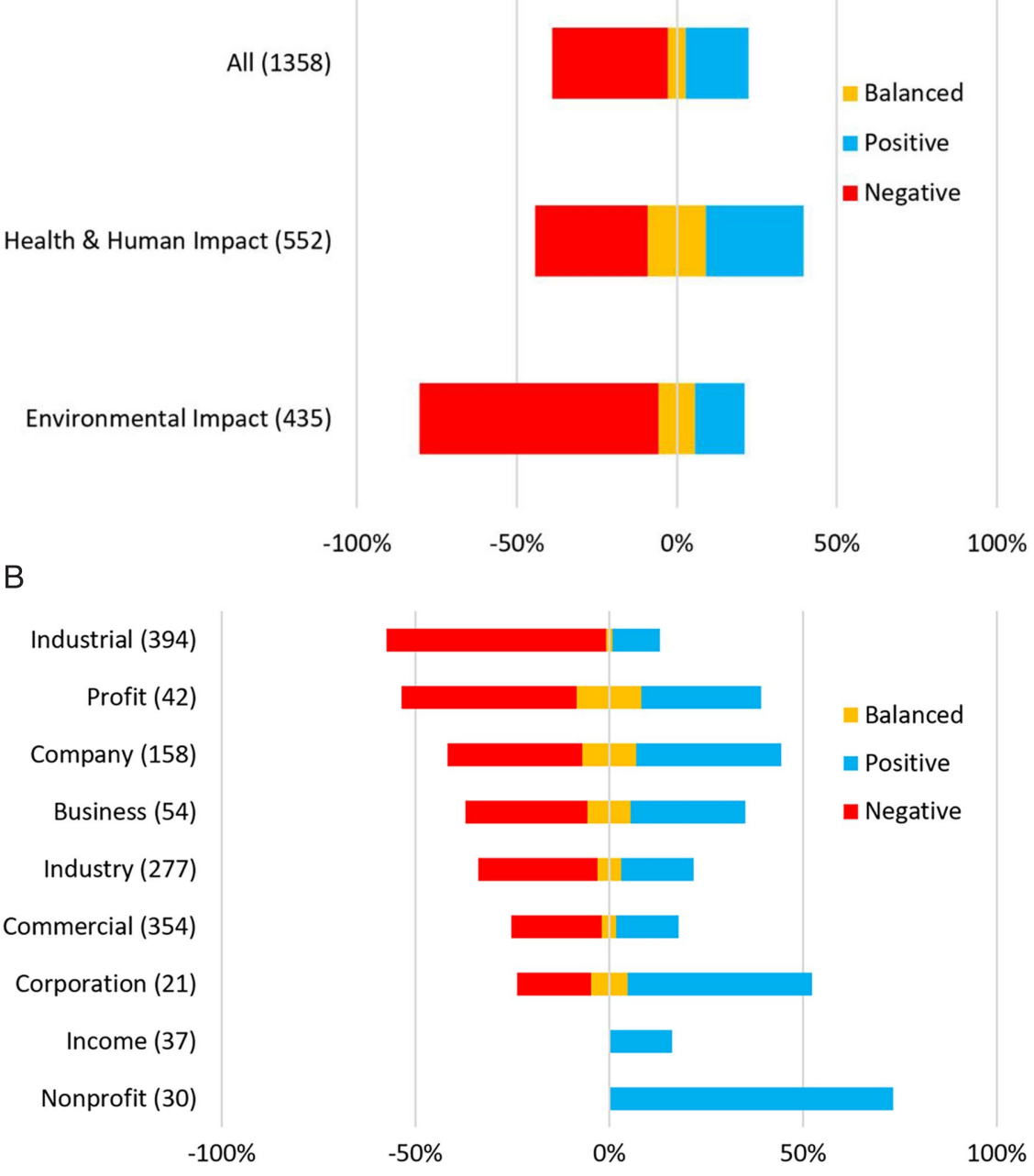

FIGURE 1. Connotations of search terms. Industry Relevant textbook passages were coded as Positive Connotation, Negative Connotation, Balanced (having both Positive Connotation and Negative Connotation), or Neither. The number of terms analyzed is listed in parentheses to the right of each label. (A) Connotations associated with search term, including all terms in all textbooks, or terms coded as either Human Impact or Environmental Impact. (B) Connotations of individual search terms.

which only 18 were rated as Career Relevant. The remaining search terms were part of historical or biographical vignettes, metaphors, generalizations, or homonyms to "occupation" related to living in a specific habitat.

An example of a Career Relevant passage is

We cannot urge you strongly enough, even if you are not contemplating a career in biology, to join in the journey of biological discoveries throughout your life. (Audesirk et al., 2005, p. 15)

In addition to references to general career decisions, such as the one just presented, a few examples illustrated careers in STEM. As an example,

Having a shot at fame and fortune quickens the pulse of men and women in any profession, and scientists are no exception. (Starr et al., 2007, p. 139)
Notably, the NVivo search identified no passages referring specifically to careers in industry.

\section{Industry Relevant Passages}

NVivo identified 2237 passages with terms from the business lexicon across more than 25,000 pages of text. Of these, 1358 passages used the words from the lexicon specifically, with Industry Relevant rating, as defined by the coding guidebook (average, 47 passages per book, range 1-86 passages per book). The word "incorporated" was used exclusively as a homonym meaning "included, as part of a whole" and was never classified as Industry Relevant (Brookes, 2004).

\section{Passages with Human Impact or Environmental Impact}

Each Industry Relevant passage was coded separately for Human Impact or Environmental Impact according to the coding guidebook (Supplemental Table 2) and could be coded as Human Impact, Environmental Impact, both, or neither (Table 1). We coded passages as Human Impact if the Industry Relevant term involved human health or nutrition, including industries engaged in biotechnology, pharmaceutical, or agricultural activities that support, harm, or otherwise affect human health. We did not include passages that referred to bacterial antibiotic resistance or biofuel crops unless they explicitly referred to human impacts.

An example of a Human Impact passage is

Several independent organizations launched their own versions of the Human Genome Project. Walter Gilbert started one company and declared he would sequence and patent the human genome. (Starr et al., 2006, p. 250)

This passage shows an example of a scientist creating a corporate entity to pursue a societal goal of cataloging the complete human genome for medical research. Of the 1358 Industry Relevant passages, 552 were coded as Human Impact (Table 1).

Passages were coded as Environmental Impact if they referred to industrial products or business practices that supported, harmed, or otherwise affected habitat composition, species biodiversity or extinction, or environmental sustainability. This categorization does not include "business environments" that refer to financial or market conditions.

An example of an Environmental Impact passage is

Almost 70\% of commercial ocean fish populations have been fully exploited or overfished, and many formerly abundant fish 
populations, such as cod harvested off New England, Canada, and in the North Sea, have collapsed because of overfishing. (Audesirk et al., 2005, p. 813)

The passage above was coded as Environmental Impact because of the effect of commercial activity on fish populations. A total of 435 passages were coded as Environmental Impact (Table 1).

Some passages were coded as having both Human Impact and Environmental Impact. For example,

One concern is that large corporations that own many farms, called agribusiness corporations, are profiting so much from GM crop production that they will put owners of family farms out of business. Other concerns focus on the impact of GMOs on human health and the environment. (Belk and Maier, 2007, p. 210)

This passage was coded as having both Human Impact and Environmental Impact because of the explicit concerns expressed about corporate use of genetically modified organisms on both health and environment.

\section{Passages with Positive Connotation and Negative Connotation}

Each Industry Relevant passage was coded separately as having Positive Connotation or Negative Connotation according to the definitions, inclusions, and exclusions in the coding guidebook (Supplemental Table 2). Because connotations were coded independently, a passage could be classified as having both Positive Connotation and Negative Connotation (Balanced), or could be classified as having neither Positive Connotation nor Negative Connotation if neither code fit the passage (Table 1 and Figure 1).

Passages were coded as Positive Connotation if they focused on industries providing scientific advances; beneficial contribution to health, wellness, environmental sustainability; or benefits to the public. We specifically coded passages as having Positive Connotation if they described success in business, including passages describing income, profits, or monetary gain. Passages were coded as Negative Connotation if they focused on ethical lapses, environmental degradation, or risks to public health or well-being as a result of business products or practices. We did not assign either Positive or Negative Connotation codes to potentially controversial topics, for example, genetic modifications, cloning, or environmental use of pesticides, unless positive or negative implications were explicitly stated.

Of the 1358 Industry Relevant passages, 268 (20\%) were coded as Positive Connotation (Table 1 and Figure 1). Among passages classified in this way are those that mention industry in connection with providing treatments for disease. For example,

A transgenic organism is one that receives recombinant DNA. In the pharmaceutical industry, transgenic bacteria produce several dozen drugs, including human insulin to treat diabetes, blood clotting factors to treat hemophilia, immune system biochemicals, and fertility hormones. (Hoefnagels, 2009, p. 252)
The passage was coded as Positive Connotation because of the pharmaceutical industry's production of drugs and for the direct references to treatment of diabetes and hemophilia. It was also coded as Human Impact because of the relevance to human disease. Of the 552 passages coded as having Human Impact, 169 (31\%) were also classified as Positive Connotation (Table 1 and Figure 1).

Of the 435 passages coded Environmental Impact, 64 (15\%) were also classified as Positive Connotation (Table 1 and Figure 1). Two examples identified with the search term "company" describe impacts that promote sustainable practice and were classified as Positive Connotation:

The National Institute of Biodiversity of Costa Rica collects and identifies species that look promising and sends in chemical samples extracted from them to one company. If natural chemicals end up being marketed, Costa Rica will share the royalties, which are earmarked for conservation programs. (Starr et al., 2007, p. 553)

[Statoil] it's environmentally friendly, and it has given the company a reputation as a global leader in carbon sequestration. At the moment, Sleipner West is the only facility in the world sequestering carbon on such a large scale. (Johnson, 2010, p. 486)

A total of 492 passages (36\%) were coded as Negative Connotation. For passages coded as Human Impact, 194 (35\%) were also classified as Negative Connotation (Table 1 and Figure 1). As an example,

What do you think would be the fairest way to hold a large drug company responsible for damages done by one of its drugs? (Johnson, 2010, p. 214)

This passage was coded as Negative Connotation, because it explicitly references "damages done by one of its drugs." Note that this passage does not associate any positive connotations with the company or its drugs.

There were many passages that described environmental damage done through industrial practices. In fact, 325 (75\%) of the passages coded as Environmental Impact were also classified as Negative Connotation (Table 1 and Figure 1). Examples include

Industry spews tons of pollutants into the atmosphere. (Solomon et al., 2008, p. 1016)

Cities such as New York, Boston, and Philadelphia are known as gray-air cities because the pollutants in the air are usually sulfur oxides emitted by industry. (Johnson and Losos, 2010, p. 806)

Clean-water and clean air legislation in the early 1970s prevented venting industrial wastes into the atmosphere and flushing them into waterways. Industry turned to land disposal, which was unregulated at the time. (Mader, 2007, p. 618)

Some passages embodied both Positive Connotation and Negative Connotation associated with a single Industry Relevant 
terms. We classified these passages as having both Positive Connotation and Negative Connotation (Balanced). Examples include

Opponents of human DNA patents argue that human genes are being treated like commodities. They suggest that reducing humans to a DNA sequence is an assault on our dignity. Proponents argue that the patent system helps improve human health by stimulating biotechnology companies to invest in genetic screening programs. (Mader, 2007, p. 245)

In the preceding passage, both the goals for company patents on DNA sequences (Positive Connotation) and their potential drawbacks (Negative Connotation) are presented. As another Balanced example,

Most tropical countries allow commercial logging to proceed much faster than is sustainable, because it supplies them with much-needed revenues. (Solomon et al., 2008, p. 1225)

In the preceding passage, commercial activities are associated with environmentally unsustainable practices (Negative Connotation) while acknowledged for providing much-needed economic benefit (Positive Connotation).

\section{Synergy and Conflict}

In addition to overall Positive Connotation and Negative Connotation, described in the preceding section, we coded Industry Relevant passages as showing Synergy or Conflict between the practice of science and the practice of business. Synergies include cases of collaboration between scientific and business processes, including corporate funding of research, employment or contracting of scientists within a business, or patenting or licensing of technology for commercial use. Passages were classified as Conflict if science was portrayed as impeding the progress of industry, or vice versa. Examples include using patents to restrict researcher access to data or conflicts of interest introduced by industrial funding. Synergy and Conflict codes were applied independently of Positive Connotation and Negative Connotation, because there is no value judgment required to describe the concepts.

We classified 142 Industry Relevant terms as Synergy. Examples include

This international undertaking, based on the DNA from 6-10 anonymous individuals, was essentially completed in 2001 by hundreds of researchers working in two independent teams, the government-funded International Human Genome Sequencing Consortium and the privately funded company Celera Genomics. (Solomon et al., 2008, p. 349)

The passage above represents Synergy because of the "hundreds of researchers" performing genome-sequencing research (science) in a company (industry) setting.

In 1980, Stanford and UC were issued the "Cohen-Boyer" patent, under which both universities, along with Cohen and Boyer, were paid royalties by every biotech company that wanted to employ the Cohen-Boyer technique. (Krogh, 2007, p. 240)
This passage shows how the practice of science by Cohen and Boyer resulted in a patent that enabled their technique's legitimate use by biotech companies. The scientists benefited from royalties for their work, while the companies benefited from access to the technique.

Watson and Crick's discovery opened the way for numerous advances in fields such as medicine, forensics, pharmacology, and agriculture, and eventually gave rise to the current rapid growth of the biotechnology industry. (Russell et al., 2008, p. 278)

This passage shows an example of one scientific discovery's benefit to many types of business, even to the point of launching a new industry.

We classified only 16 examples of overt Conflict between the practice of science and the practice of business. Several of these examples imply a perceived conflict of interest between the financial goals of business and the impartiality of scientific research, including

Is it too early to be using this procedure on patients? Is the company opening itself up to lawsuits? In other words, is it letting financial concerns outweigh the need for good scientific research and carefully controlled experiments? (Chiras, 2008, p. 204)

A 2004 study found that drug company-funded research is more favorable to new drugs than is publicly funded research. (Hoefnagels, 2009, p. 47)

Only one example presented patents as restrictive to scientific enterprise, and even this restriction is qualified:

Genomes should be freely available to all and should not be patented. Private companies patent gene functions, but they often make sequence data available with certain restrictions. (Losos et al., 2008, p. 366)

\section{Additional Findings}

Irregular, Illegal, or Fraudulent Industry Practices. We found a number of passages that specifically referenced companies engaged in irregular, illegal, or fraudulent practices. This suggests an ascertainment bias. For example, while there are more than 3000 biotechnology companies in the United States, including more than 300 public companies with a combined value greater than \$1 trillion in 2015 (Morrison and Lähteenmäki, 2016), three of the 11 biotechnology companies identified by name in these passages were shadow companies with fundamentally fraudulent products and practices.

Examples of such representations include

United States-based company Clonaid claimed that it had created the first-ever cloned human baby. (Enger et al., 2009, p. 629)

Clonaid is not a mainstream biotechnology company, but rather a corporate entity associated with the Raëlian Movement, a UFO religion generally considered to be a cult (McDowell, 2003). Another example of fraudulent practices in industry follows: 
Baby Gender Mentor is not regulated by the FDA, and the company won't release the "scientific information" on which their 99.9\% accuracy is based. Blog sites are reporting that the test is not nearly as accurate as claimed by the company. (Johnson, 2010, p. 427)

The company Acu-Gen developed Baby Gender Mentor. While the company received extensive publicity after being featured on the Today Show in 2005, no evidence was presented to back their claims (Bianchi, 2006). The company declared bankruptcy in 2009 amid many lawsuits and an injunction requiring them to issue a recall (Donnelly, 2009).

Similarly, while only 32 of the 1494 drugs approved by the FDA have ever been withdrawn (Kinch et al., 2014), we found five passages discussing Vioxx, which was withdrawn from the market after the manufacturer, Merck, was found to have underreported the risk of heart attacks in clinical trials with the drug (Krumholz et al., 2007). For example,

Clinical trials sometimes reveal undesirable and harmful side effects of a drug. Failure to reveal those side effects is another form of scientific fraud. It is alleged that the company that manufactures Vioxx failed to report the results of trials that showed the drug increased the risk of heart attack. (Goodenough et al., 2007, p. 57)

While the passage accurately describes the circumstances surrounding the withdrawal of Vioxx, these circumstances are not typical of the tens of thousands of clinical trials performed each year (Viergever and Li, 2015). Of seven Industry Relevant passages mentioning "clinical trial(s)," five incorporated negative connotations.

Simplistic Depictions of Business. Although we did not code these passages explicitly, we noticed a number of passages that presented caricatures of business practices that would be perceived as simplistic to students engaged in the undergraduate study of business. Examples of passages that business students might perceive as simplistic include

Just as the CEO of a major company issues commands from headquarters instead of from the factory floor, DNA issues instructions from the cell nucleus and not from the cytoplasm where the cell's work is done. (Goodenough et al., 2007, p. 494)

Business majors at the undergraduate level take courses in management principles and best practices, and would recognize that command and control is an ineffective approach to management that would be rarely used in a "major company." Business students might find this passage to be simplistic and uninformed about business. Another example:

You are the CEO of a drug company. A research scientist approaches you with a plan to develop a new muscle-relaxing drug. The scientist explains that the drug works by flooding the muscle cell with calcium ions. Would you finance the development of this drug? Why or why not? (Goodenough et al., 2007, p. 155)
Undergraduate business majors are encouraged to consider many different factors, such as market needs, competitive stance, existing infrastructure, and financial projections when making decisions to pursue or forgo business projects. Business students presented with a question like this would likely conclude that they did not have the necessary information to formulate an evidence-based response. Making a decision based solely on the biology of calcium's role in muscle contraction would be considered inappropriate.

Ecosystem conversion always has a cost and a benefit. Usually the benefit flows to a segment of society (a business or one group of people, for instance), but the costs are borne by all of society. (Losos et al., 2008, p. 1289)

Business students might find that this passage contradicts instruction they received in economics or in management courses, for example, principles associated with stakeholder theory of organizational management (Freeman and Reed, 1983).

Such simplistic representations of business practice, while they may be intended to engage business students, could ultimately alienate these students from science courses. Business students take courses in management, finance, economics, and marketing that are, a priori, no less rigorous than STEM courses and also strive to teach critical thinking. Simplistic representations of business practices could suggest to these students that science course content is, in fact, less rigorous than their business courses. The students may conclude that scientific considerations are fundamentally at odds with their business training, as opposed to recognizing that STEM courses provide important skills that are transferable to their business careers.

Representation of Nonprofit Entities. The search for "nonprofit" or "nonprofit" returned 32 passages in 12 books, of which 30 were rated as Industry Relevant. Fifteen of the mentions came from a single book (Johnson, 2010), with 11 of these found in an explicit list of recommended nonprofit entities. For example,

A national nonprofit organization that provides advocacy support, and services for people with arthritis and related health conditions. National Institute of Arthritis and Musculoskeletal and Skin Diseases wvvw.niams.nih.gov. (Johnson, 2010, p. 119)

While this list skews the number of passages mentioning "non-profit" that were coded as Positive Connotation (61\%), we found no passages in which "non-profit" was coded as Negative Connotation.

Nine mentions of nonprofits were also coded as Synergy, indicating funding, practice, or other support of science by the organization. One example specifically mentions nonprofit organizations but not for-profit companies as conservation resources:

You can participate in group conservation efforts by joining nonprofit organizations focused on these issues, writing to politicians, and educating others. (Belk and Maier, 2007, p. 380) 


\section{DISCUSSION}

"Introductory" undergraduate courses in S\&E disciplines, including biology, embody multifarious goals (NRC, 2003; Woodin et al., 2009; AAAS, 2011), particularly for nonmajors (Labov, 2004; Klymkowsky, 2005; Wright, 2005). These goals include, but are not limited to, engaging students to enroll in S\&E majors; promoting careers in STEM occupations; providing students with the skills to employ scientific evidence and evidence-based reasoning in their careers, professions, and personal lives; and engaging students in applying scientific evidence-based reasoning in civil life.

This work focuses explicitly on how textbooks for introductory biology courses represent industry. The underlying premise of our analysis is that, for the majority of students in these classes who will work in non-STEM occupations, learning may be advanced by incorporating content that describes applications of biology in industry and how science, as well as scientific evidence-based reasoning, can promote success in business occupations. This is particularly true at our institution, where $>$ $97 \%$ of students major in business disciplines and are required to complete science courses as part of a distribution requirement (Ledley, 2012; Ledley and Oches, 2013; Ledley and Holt, 2014). We have also shown that a median of two science courses is required at leading business schools in the United States (Ledley, 2012).

The first question we asked was whether these texts describe opportunities for applying STEM learning in non-STEM occupations. STEM skills are increasingly important in business occupations, especially as the high-tech industry continues to grow and provide active employment opportunities in the United States. An article in the Association to Advance Collegiate Schools of Business education magazine, BizEd, notes that business increasingly revolves "around the convergence of technologies such as computing, communications, and engineering, and the growing importance of life sciences such as physics, biology, and chemistry" (McCann, 2006, para. 5). Professors of management and business professionals agree that knowledge of science, including an understanding of the nature of science and technology and the strategic role of technological innovation in business, is important for managers of innovative industries (Mallick and Chaudhury, 2000). Van Wyk and Gaynor (2014) propose an academic template for engineering and technology management graduate programs to include knowledge of technology and technology-linked management as a core expertise. The International Association for Management of Technology recommends its educational programs include technology-related knowledge, knowledge of corporate functions, and knowledge of supporting disciplines for managers of technology-intensive industries (Yanez et al., 2010). We take these studies to underscore the importance of STEM knowledge and skills in the modern workforce.

We identified very few passages describing business occupations where STEM learning could be relevant to professional success. Glynn et al. (2007) showed that student recognition of the relevance of science to their careers was an important factor both in their motivation to learn and in their overall achievement in science. The absence of explicit examples showing this relevance is a missed opportunity to advance student learning. Potential examples might address how knowledge of biology contributes to success as an executive or investor in the healthcare, food, cosmetics, or agriculture industries, or to success in occupations such as marketing, sales, or supply chain management.

The second question we asked was whether these textbooks provide content for context-based learning. Evidence shows that student learning in science can be improved by teaching scientific principles in a context that is familiar to students (Brown et al., 1989; NRC, 1999). Context-based learning stems from the observation that memory is reinforced by connecting new information to established memories and other contextual clues. Moreover, the more closely new information can be connected to existing cues, and the more connections to cues that can be established, the greater the efficiency of information retention and retrieval. This is the principle underlying the American Chemical Society's Chemistry in Context (Middlecamp, 2008; American Chemical Society, 2009), the Mathematics for Business Decisions curriculum (Ganter and Barker, 2004; Thompson et al., 2005), and the Biology for Business, Law, and Liberal Arts course at the University of Texas (Bull, 2016).

We identified very few examples of scientific content being presented in the context of industrial applications. Most prominent were examples of the use of biotechnology to produce commercial products and the addition of nitrogen and phosphorous to industrial fertilizers for enhancing crop yields. This was surprising, given the foundational role played by biological science in fields such as biopharmaceuticals, healthcare, food, and agriculture. We believe this is a missed opportunity to enhance STEM learning for the majority of students enrolled in introductory biology courses.

Third, we asked whether the texts provided constructive heuristic models for the application of STEM learning in industry. This question was prompted by the often-conflicted relationship between the sciences and industry. On one hand, the scientific and business communities are inextricably linked. Scientific enterprise provides the lifeblood for industry, delivering the technological insights and inventions that underlie new commercial and economic opportunities, as well as the trained workforce required for increasingly technology-driven and technology-dependent companies. The biopharmaceutical industry, for example, spends more than $\$ 100$ billion annually on biomedical research and development, an investment significantly larger than that made by government and nonprofit institutions combined (Moses et al., 2005, 2015).

On the other hand, there is a perceived "conflict of interest" between industry and the pursuit of responsible science and science-based policy (Johnston, 2008; Lo and Field, 2009; Kesselheim et al., 2012). This conflict is manifest, for example, in scholarly articles suggesting that research funded by industry may be inherently biased (Lexchin et al., 2003; Lundh et al., 2012; Bero, 2013), as well as by studies from industry suggesting that academic research is often of poor quality and irreproducible (Prinz et al., 2011; Begley and Ellis, 2012). Given the fact that textbook authors generally come from the ranks of academic scientists, it is not surprising that many would harbor the sense that science and industry are in conflict.

While we found few textbook passages explicitly describing conflicts between industry and science, we found that Industry Relevant terms were more likely to be associated with a Negative Connotation than a Positive Connotation (36\% vs. 20\%). Moreover, we identified a disproportionate number of passages 
describing companies engaged in irregular, illegal, or fraudulent practices relative to the frequency of such occurrences in practice.

To be clear, our point is not that malfeasance, fraud, and unsustainable practices do not exist in industry, but that the number of references to such behaviors has the potential to undermine the objectives of STEM learning. By emphasizing the negative, these texts undermine the opportunity to provide content for context-based learning and may actively disengage students interested in business careers. Students may conclude that they must make a polarized choice between scientific modes of thinking and personal aspiration to success in business occupations. Moreover, by promoting heuristics in which there are irreconcilable differences between scientific and business perspectives, such references may make it more difficult for students to recognize how STEM learning and science-based reasoning can be employed constructively in business occupations.

A body of cognitive science research demonstrates that perception is inherently reference dependent (Kahneman, 2002). People have a strong tendency to base judgments and "anchor" perspectives based on initial, intuitive impressions (De Neys and Bonnefon, 2013), and it is often difficult to move beyond uncritical reactions in analytical processes (Tversky and Kahneman, 1992). These initial impressions arise from a variety of heuristics, for example, anchoring heuristics, availability heuristics, or representative heuristics, which provide often-stereotyped characterizations of observed reality, rather than critical analysis (Tversky and Kahneman, 1973; Haselton et al., 2005).

Heuristics are known to play a significant role in business, contributing to human dynamics in decision making and organizational behavior (Hammond et al., 1998; Loock and Hinnen, 2015); managerial intuition (Dane and Pratt, 2007); strategic management (Krabuanrat and Phelps, 1998; Kahneman et al., 2011); and the performance of managers, investors, and entrepreneurs (Simon, 1979; Hammond et al., 1998; Loock and Hinnen, 2015). Indeed, intuition is often highly valued in business leaders (Hayashi, 2001). Thus, the ability of students to constructively apply STEM learning in business professions is likely to depend not only on their ability to apply critical, scientific reasoning in business situations, but also on the heuristics that contribute to intuition and judgment.

Scholars have described textbooks as a form of "mass media" that is prepared by professional (faculty) authors and transmitted to large, diverse audiences (Dennis and DeFleur, 2009). Research shows that the mass media plays a significant role in the formation of heuristics. Mass media has been described as having an "agenda-setting function" (McCombs and Shaw, 1972). This theory describes the ability of media to influence the salience of topics in the mind of the public through heuristics. The agenda-setting function results from the aggregate impact of many repetitions, rather than from critical analysis of salient facts. This framing process sets an agenda that promotes various definitions, causal factors, and moral evaluations (Entman, 2007). The media's focus on sensationalism and negative news stories (e.g., the Vioxx recall) has been shown to have a significant influence on the public perception of corporations (Carroll and McCombs, 2003). Like mass media, the passages we identified promote hyped and unfavorable stereotypes of industry, without providing counterexamples of responsible actions or engaging in critical analysis.

In this context, we are concerned that this focus on negative industry practices could contribute to heuristics that reinforce the impression that such behaviors are normative. Faced with similar behaviors in business occupations, students may initially build on such representative heuristics, making it more difficult to respond based on a critical, scientifically grounded analysis (Cialdini et al., 2006; Golstein and Cialdini, 2009). While the textbook authors' intent in relating instances of improper corporate behaviors may have been to caution students against such practices, presenting this information alongside scientific facts may instead inadvertently reinforce heuristics that perpetuate such practices.

We are concerned that negative representations of industry may tacitly give students implied permission to behave unethically when they become employed in business themselves. A recent study looking at representations of race in classroom materials showed that including examples of racial differences in a genetics text negatively impacted student attitudes toward race, their willingness to socialize across racial lines, and their acceptance of educational interventions to reduce racial inequality (Donovan, 2017). One could design an analogous study that compares teaching materials with different representations of industry to assess their impact on students. On a larger scale, one could compare student engagement and outcomes of courses similar in design to Chemistry in Context that present biology in the context of the non-STEM occupations, as well as STEM occupations.

There are several limitations to this study. First, we acknowledge that the purpose of the study is simply to characterize representation of industry in textbooks rather than to show the effects of these representations on student outcomes, although this would be an intriguing topic for future research. Additionally, our methods identify only passages that incorporated Industry Relevant terms. These methods do not identify passages that may describe industrial activities without explicitly using our terminology. For example, this analysis would not identify discussion of clinical trials conducted by industry, unless the passage explicitly noted the industry association. This analysis may also have missed passages that mentioned a company by name, without also using Industry Relevant term or appending the term "Incorporated" ("Inc.") or "Company" ("Co."). We also note that undergraduate textbooks undergo frequent updates, and our analysis did not always capture content from the most recently published version of the books in our database. Our analysis represents a time-limited snapshot of popular textbooks. Conducting a similar analysis as textbooks become updated, new textbooks appear, and textbooks lose popularity within biology classrooms may show interesting trends in the importance and perception of industry in introductory STEM textbooks. We applied our search and coding methods to two newer textbook versions and found no significant differences in industry representation between these texts and earlier versions.

More importantly, this analysis is limited by its focus on textbooks for undergraduate biology in an age when faculty and students have access to a great deal of additional content online. We currently have no reason to believe that representation of industry in classroom instruction will deviate significantly 
from what we identified in textbooks. In a previous study, we interviewed some of the authors of the textbooks used in our current study and found that their content is significantly shaped by the perspectives and curricula of in-service teachers (Wernick et al., 2014). It will be important to similarly examine representations of industry in Open Educational Resources and other online or customized content.

One of the recognized goals of undergraduate science education is to engage students in learning not only scientific principles, but also the evidence-based, critical-reasoning skills necessary for informed citizenship (Labov, 2004; Labov and Huddleston, 2008; Labov et al., 2010; Middlecamp et al., 2006). There is extensive literature on how science courses can promote student advocacy for sustainability, public health, public policy, and global citizenship (Middlecamp et al., 2006; Labov and Huddleston, 2008; Sheardy, 2010; Smith et al., 2015). However, few authors of biology textbooks have any formal education or in-depth knowledge of business. The authors themselves may be subject to the agenda-setting activities of media and heuristics that bring negative examples of business behaviors to mind. Moreover, students have access to many of their own sources of information both inside and outside the classroom that can affect their learning, preferences, goals, and biases independent of content in their introductory biology texts. A more critical analysis of the intersection of science and industry could better serve the goals of promoting socially responsible behaviors of students who take these courses in preparation for careers in business.

Instructional content that describes constructive applications of scientific knowledge and reasoning in business situations could contribute to heuristics that recognize the synergies of science and industry. Passages such as those describing the health benefits of pharmaceutical products, positive impacts of investments in R\&D, innovative plans for carbon capture, and the creative business strategies of successful biodiversity projects, as already included in the textbooks, represent exemplars of our suggested language to guide graduates toward the constructive application of scientific learning. Such content could contribute to an agenda of corporate social responsibility by raising the accessibility and salience of socially responsible behavior (Carroll and McCombs, 2003). Additionally, case studies that encourage critical thinking about the issues involved at the intersection of science and industry could promote both understanding of the relevance of STEM perspectives in industry and engagement of business-focused students in STEM learning. The National Center for Case Study Teaching in Science has many case studies that examine applications of biology in biotechnology, agriculture, and other industries (Herreid, 2007; Herreid and Schiller, 2013). Similarly, many case studies have been developed for instruction in corporate social responsibility, including the "Sustainability Case Studies" in the Learning Edge Resource at the MIT Sloan School (Massachusetts Institute of Technology, 2017), and cases studies related to public health in Consumers, Corporations, and Public Health: A Case-Based Approach to Sustainable Business (Quelch, 2016). There are also many collections of business case studies describing applications of science and technology in both product development and business process innovation, among them a case study describing the combination of scientific and business decisions in the development of HUMIRA by Abbot Laboratories (Denend et al., 2015). Finally, there is increasing emphasis on internships and mentored work experiences in undergraduate education (Akins, 2005), which may be effective in modeling applications of STEM learning in various occupations and advancing context-based STEM learning for business-focused students. We hope through this study to raise awareness of the representation of business in introductory biology classes and to empower both authors and teachers to consciously include representative examples for use of STEM learning to benefit their students' future careers.

\section{ACKNOWLEDGMENTS}

This work was supported by grants from the National Biomedical Research Foundation and the Jeanne and Dan Valente Center for Arts and Sciences at Bentley University. We thank Qi $\mathrm{Xu}$, Dr. David Szymanski, Dr. Naomi Wernick, and Danielle Solar for their contributions to this work.

\section{REFERENCES}

Akins, T. M. (2005). A brief summary of cooperative education: History, philosophy, and current status. In Educating the engineer of 2020: Adapting engineering education to the new century (pp. 61-68). Washington, DC: National Academies Press

Allum, J. (2013). Outcomes for PSM alumni: 2012/13. Washington, DC Council of Graduate Schools.

Alper, J. (2016). Developing a national STEM workforce strategy: A workshop summary. Washington, DC: National Academies Press.

American Association for the Advancement of Science. (2011). Vision and change in undergraduate biology education: A call to action (Final report). Washington, DC.

American Chemical Society. (2009). Chemistry in context: Applying chemistry to society. New York: McGraw-Hill Higher Education.

Audesirk, T., Audesirk, G., \& Byers, B. E. (2005). Biology: Life on earth (7th ed.). Upper Saddle River, NJ: Pearson Prentice Hall.

Begley, C. G., \& Ellis, L. M. (2012). Drug development: Raise standards for preclinical cancer research. Nature, 483(7391), 531-533.

Belk, C. M., \& Maier, V. B. (2007). Biology: Science for life with physiology (2nd ed.). Upper Saddle River, NJ: Pearson Prentice Hall.

Bero, L. (2013). Industry sponsorship and research outcome: A Cochrane review. Journal of the American Medical Association Internal Medicine, $173(7), 580-581$

Bianchi, D. W. (2006). At-home fetal DNA gender testing: Caveat emptor. Obstetrics \& Gynecology, 107(2), 216-218.

Brint, S., Proctor, K., Murphy, S. P., Turk-Bicakci, L., \& Hanneman, R. A. (2009) General education models: Continuity and change in the US undergraduate curriculum, 1975-2000. Journal of Higher Education, 80(6), 605-642.

Brookes, I. (2004). Chambers concise dictionary. Edinburgh: Chambers.

Brown, J. S., Collins, A., \& Duguid, P. (1989). Situated cognition and the culture of learning. Educational Researcher, 18(1), 32-42.

Bull, J. (2016). Bio301D: Biology for business, law, and liberal arts (course materials). Retrieved September 4, 2018, from https://utw10426.utweb utexas.edu/

Carroll, C. E., \& McCombs, M. (2003). Agenda-setting effects of business news on the public's images and opinions about major corporations. Corporate Reputation Review, 6(1), 36-46.

Chiras, D. D. (2008). Human biology (6th ed.). Sudbury, MA: Jones and Bartlett.

Cialdini, R. B., Demaine, L. J., Sagarin, B. J., Barrett, D. W., Rhoads, K., \& Winter, P. L. (2006). Managing social norms for persuasive impact. Social Influence, 1(1), 3-15. doi: 10.1080/15534510500181459

Connelly, T., \& Sharp, P. (2009). A new biology for the 21st century. Washington, DC: National Academies Press.

Dane, E., \& Pratt, M. G. (2007). Exploring intuition and its role in managerial decision making. Academy of Management Review, 32(1), 33-54. 
Denend, L., Zenios, S., \& Chess, R. (2015). Abbott Laboratories and HUMIRA: Launching a blockbuster drug. Stanford Graduate School of Business, No. OIT-44. Stanford, CA: Stanford Graduate School of Business.

De Neys, W., \& Bonnefon, J. F. (2013). The "whys" and "whens" of individual differences in thinking biases. Trends in Cognitive Sciences, 17(4), 172178.

Dennis, E. E., \& DeFleur, M. L. (2009). Understanding media in the digital age London: Allyn \& Bacon.

Donnelly, J. M. (2009, December 17). Acu-Gen Biolab files for Ch. 11 bankruptcy. Boston Business Journal. Retrieved September 4, 2018, from www.bizjournals.com/boston/blog/mass-high-tech/2009/12/acu-gen -biolab-files-for-ch-11-bankruptcy.html

Donovan, B. M. (2017). Learned inequality: Racial labels in the biology curriculum can affect the development of racial prejudice. Journal of Research in Science Teaching, 54(3), 379-411. doi: 10.1002/tea.21370

Enger, E. D., Ross, F. C., \& Bailey, D. (2009). Concepts in biology (13th ed.). New York: McGraw-Hill.

Entman, R. M. (2007). Framing bias: Media in the distribution of power Journal of Communication, 57(1), 163-173.

Freeman, R. E., \& Reed, D. L. (1983). Stockholders and stakeholders: A new perspective on corporate governance. California Management Review. 25(3), 88-106

Fuhrmann, C. N., Halme, D., O'Sullivan, P., \& Lindstaedt, B. (2011). Improving graduate education to support a branching career pipeline: Recommendations based on a survey of doctoral students in the basic biomedical sciences. CBE-Life Sciences Education, 10(3), 239-249.

Ganter, S. L., \& Barker, W. (2004). The Curriculum Foundations Project: Voices of the partner disciplines. Washington, DC: Mathematical Association of America.

Gibbs, K. D. Jr, McGready, J., Bennett, J. C., \& Griffin, K. (2014). Biomedical science Ph.D. career interest patterns by race/ethnicity and gender. PLoS ONE, 9(12), e114736.

Glynn, S. M., Taasoobshirazi, G., \& Brickman, P. (2007). Nonscience majors learning science: A theoretical model of motivation. Journal of Research in Science Teaching, 44(8), 1088-1107.

Golstein, N., \& Cialdini, R. B. (2009). Normative influences on consumption and conservation behaviors. In Wanke, M. (Ed.), Social psychology and consumer behavior (pp. 273-296). New York: Psychology Press.

Goodenough, J., MacGuire, B., \& Wallace, R. A. (2007). Biology of humans: Concepts, applications and issues (2nd ed.). Upper Saddle River, NJ: Pearson Prentice Hall.

Hammond, J. S., Keeney, R. L., \& Raiffa, H. (1998). The hidden traps in decision making. Harvard Business Review, 76(5), 47-58.

Haselton, M. G., Nettle, D., \& Murray, D. R. (2005). The evolution of cognitive bias. In Buss, D.M. (Ed.), The handbook of evolutionary psychology (pp 724-746). Hoboken, NJ: Wiley.

Hayashi, A. M. (2001). When to trust your gut. Harvard Business Review, 79(2), 59-65.

Herreid, C. F. (2007). Start with a story: The case study method of teaching college science. Arlington, VA: NSTA Press.

Herreid, C. F., \& Schiller, N. A. (2013). Case studies and the flipped classroom Journal of College Science Teaching, 42(5), 62-66.

Hoefnagels, M. (2009). Biology: Concepts and investigations. New York: McGraw-Hill.

Holdren, J., Marrett, C., \& Suresh, S. (2013, May 31). Federal science, technology, engineering, and mathematics (STEM) education 5-year strategic plan. Retrieved September 4, 2018, from https://obamawhitehouse .archives.gov/sites/default/files/microsites/ostp/stem_stratplan_2013 pdf

Johnson, G. B., \& Losos, J. B. (2010). The living world (6th ed.). New York: McGraw-Hill.

Johnson, M. D. (2010). Human biology: Concepts and current issues (5th ed.). San Francisco: Pearson Benjamin Cummings.

Johnston, J. (2008). Conflict of interest in biomedical research. In Crowley, M. (Ed.), From birth to death and bench to clinic: The Hastings Center bioethics briefing book for journalists, policymakers, and campaigns (pp. 31-34). Garrison, NY: Hastings Center.
Kahneman, D. (2002). Prize Lecture. NobelPrize.org. Nobel Media AB 2018 Retrieved September 4, 2018, from www.nobelprize.org/uploads/2018/ 06/kahnemann-lecture.pdf

Kahneman, D. (2003). Maps of bounded rationality: Psychology for behavioral economics. American Economic Review, 93(5), 1449-1475. doi: 10.1257/000282803322655392

Kahneman, D. (2011). Thinking, fast and slow. New York: Farrar, Straus and Giroux.

Kahneman, D., Lovallo, D., \& Sibony, O. (2011). Before you make that big decision. Harvard Business Review, 89(6), 50-60.

Kesselheim, A. S., Robertson, C. T., Myers, J. A., Rose, S. L., Gillet, V., Ross, K. M., ... Avorn, J. (2012). A randomized study of how physicians interpret research funding disclosures. New England Journal of Medicine, 367(12), 1119-1127.

Kinch, M. S., Haynesworth, A., Kinch, S. L., \& Hoyer, D. (2014). An overview of FDA-approved new molecular entities: 1827-2013. Drug Discovery Today, 19(8), 1033-1039.

Klymkowsky, M. W. (2005). Points of view: Content versus process: Is this a fair choice? Can nonmajors courses lead to biological literacy? Do majors courses do any better? Cell Biology Education, 4(3), 196-198.

Krabuanrat, K., \& Phelps, R. (1998). Heuristics and rationality in strategic decision making: An exploratory study. Journal of Business Research, 41(1), 83-93.

Krogh, D. (2007). A brief guide to biology. Upper Saddle River, NJ: Pearson Education.

Krumholz, H. M., Ross, J. S., Presler, A. H., \& Egilman, D. S. (2007). What have we learnt from Vioxx? British Medical Journal, 334(7585), 120-123.

Labov, J. B. (2004). From the National Academies: The challenges and opportunities for improving undergraduate science education through introductory courses. Cell Biology Education, 3(4), 212-214.

Labov, J. B., \& Huddleston, N. F. (2008). Integrating policy and decision making into undergraduate science education. CBE-Life Sciences Education, 7(4), 347-352.

Labov, J. B., Reid, A. H., \& Yamamoto, K. R. (2010). Integrated biology and undergraduate science education: A new biology education for the twenty-first century? CBE-Life Sciences Education, 9(1), 10-16.

Landivar, L. C. (2013). The relationship between science and engineering education and employment in STEM occupations (Report no. ACS-23). Washington, DC: U.S. Census Bureau.

Ledley, F. D. (2012). Bridging the boundary between science and business. International Journal of Science in Society, 3(3), 171-194.

Ledley, F. D., \& Holt, S. S. (2014). Learning objectives and content of science curricula for undergraduate management education. Journal of Management Education, 38(1), 86-113.

Ledley, F. D., \& Oches, E. A. (2013). Business education in an age of science and technology. In Hardy, G. M., \& Everett, D. L. (Eds.), Shaping the future of business education (pp. 162-174). London: Palgrave Macmillan.

Lexchin, J., Bero, L. A., Djulbegovic, B., \& Clark, O. (2003). Pharmaceutical industry sponsorship and research outcome and quality: Systematic review. British Medical Journal, 326(7400), 1167-1170.

Lo, B., \& Field, M. J. (2009). Conflict of interest in medical research, education, and practice. Washington, DC: National Academies Press.

Loock, M., \& Hinnen, G. (2015). Heuristics in organizations: A review and a research agenda. Journal of Business Research, 68(9), 2027-2036.

Losos, J. B., Mason, K. A., Singer, S. R., Raven, P. H., \& Johnson, G. B. (2008). Biology (8th ed.). New York: McGraw-Hill.

Lundh, A., Sismondo, S., Lexchin, J., Busuioc, O. A., \& Bero, L. (2012). Industry sponsorship and research outcome. Cochrane Database of Systematic Reviews, 12. doi: 10.1002/14651858.MR000033.pub2

Mader, S. S. (2007). Essentials of biology. New York: McGraw-Hill.

Mallick, D. N., \& Chaudhury, A. (2000). Technology management education in MBA programs: A comparative study of knowledge and skill requirements. Journal of Engineering and Technology Management, 17(2), 153173.

Massachusetts Institute of Technology. (2017). Sustainability case studies. MIT Sloan School, Learning Edge. Retrieved September 4, 2018, from https://mitsloan.mit.edu/LearningEdge/sustainability/Pages/default.aspx 
McCann, J. (2006). The next economy. BizEd, 5(3), 40-44.

McCombs, M. E., \& Shaw, D. L. (1972). The agenda-setting function of mass media. Public Opinion Quarterly, 36(2), 176-187.

McDowell, N. (2003, January 7). Cloning may be "elaborate hoax" says monitor. New Scientist Magazine. Retrieved September 4, 2018, from www .newscientist.com/article/dn3234-cloning-may-be-elaborate-hoax -says-monitor/

Middlecamp, C. (2008, July 30). Chemistry in context: Goals, evidence, gaps. Retrieved September 4, 2018, from https://sites.nationalacademies .org/cs/groups/dbassesite/documents/webpage/dbasse_072619.pdf

Middlecamp, C., Jordan, T., Shachter, A. M., Oates, K. K., \& Lottridge, S. (2006). Chemistry, society, and civic engagement (part 1): The SENCER project. Journal of Chemical Education, 83(9), 1301.

Morrison, C., \& Lähteenmäki, R. (2016). Public biotech in 2015-The numbers. Nature Biotechnology, 34(7), 709-715.

Moses, H., Dorsey, E. R., Matheson, D. H., \& Thier, S. O. (2005). Financial anatomy of biomedical research. Journal of the American Medical Association, 294(11), 1333-1342

Moses, H., Matheson, D. H., Cairns-Smith, S., George, B. P., Palisch, C., \& Dorsey, E. R. (2015). The anatomy of medical research: US and international comparisons. Journal of the American Medical Association, 313(2), 174-189.

National Academy of Sciences, National Academy of Engineering, and Institute of Medicine. (2005). Rising above the gathering storm: Energizing and employing America for a brighter economic future. Retrieved September 4, 2018, from www.nap.edu/catalog/11463/rising-above-the -gathering-storm-energizing-and-employing-america-for

National Institutes of Health. (2012, June 14). Biomedical research workforce working group report. Bethesda, MD: National Institutes of Health. Retrieved September 4, 2018, from https://acd.od.nih.gov/documents/ reports/Biomedical_research_wgreport.pdf

National Research Council (NRC). (1999). How people learn: Brain, mind, experience, and school. Washington, DC: National Academies Press.

NRC. (2002). Technically speaking: Why all Americans need to know more about technology. Washington, DC: National Academies Press.

NRC. (2003). BIO2010: Transforming undergraduate education for future research biologists. Washington, DC: National Academies Press. Retrieved September 4, 2018, from www.nap.edu/read/10497/ chapter/1

NRC. (2010). Exploring the intersection of science education and 21st century skills: A workshop summary. Washington, DC: National Academies Press.

President's Council of Advisors on Science and Technology. (2012). Engage to excel: Producing one million additional college graduates with degrees in science, technology, engineering, and mathematics. Washington, DC: U.S. Government Office of Science and Technology. Retrieved September 4, 2018, from https://eric.ed.gov/?id=ED541511

Prinz, F., Schlange, T., \& Asadullah, K. (2011). Believe it or not: How much can we rely on published data on potential drug targets? Nature Reviews Drug Discovery, 10(9), 712-712.

Quelch, J. A. (2016). Consumers, corporations, and public health: A case-based approach to sustainable business. New York: Oxford University Press.

Russell, P. J., Wolfe, S. L., Hertz, P. E., Starr, C., \& McMillan, B. (2008). Biology: The dynamic science. Belmont, CA: Thomson Brooks/Cole.

Shah, A. K., \& Oppenheimer, D. M. (2008). Heuristics made easy: An effort-reduction framework. Psychological Bulletin, 134(2), 207-222. doi: 10.1037/0033-2909.134.2.207
Sheardy, R. D. (2010). Science education and civic engagement: The SENCER approach. Washington, DC: American Chemical Society.

Simon, H. A. (1979). Rational decision making in business organizations. American Economic Review, 493-513.

Smith, M. H., Ambrose, A., Worker, S., \& Schmitt-McQuitty, L. (2015). Including civic engagement as a component of scientific literacy. Science Education \& Civic Engagement, 7(2), 29-34.

Solomon, E. P., Berg, L. R., \& Martin, D. W. (2008). Biology (8th ed.). Belmont, CA: Brooks/Cole CENGAGE Learning

Starr, C., Evers, C. A., \& Starr, L. (2007). Biology: Today and tomorrow with physiology (2nd ed.). Belmont, CA: Thomson Brooks/Cole.

Starr, C., Taggart, R., Evers, C. A., \& Starr, L. (2006). Biology: The unity and diversity of life (11th ed.). Belmont, CA: Thomson Brooks/Cole.

Taylor, P., Parker, K., Fry, R., Cohn, D., Wang, W., Velasco, G., \& Dockterman, D. (2011, May 16). Is college worth it? College presidents, public assess value, quality and mission of higher education. Retrieved September 4, 2018, from https://assets.pewresearch.org/wp-content/uploads/sites/ 3/2011/05/higher-ed-report.pdf

Thompson, R., Lamoureux, C., \& Slaten, P. (2005). Mathematics for business decisions with interdisciplinary multimedia projects, Parts 1 and 2. Washington, DC: Mathematical Association of America. Retrieved September 4, 2018, from http://business.math.arizona.edu/MBD/mbd.html

Tversky, A., \& Kahneman, D. (1973). Availability: A heuristic for judging frequency and probability. Cognitive Psychology, 5(2), 207-232.

Tversky, A., \& Kahneman, D. (1974). Judgment under uncertainty: Heuristics and biases. Science, 185(4157), 1124-1131.

Tversky, A., \& Kahneman, D. (1992). Advances in prospect theory: Cumulative representation of uncertainty. Journal of Risk and Uncertainty, 5(4), 297323.

U.S. Census Bureau. (2011). American community survey. Retrieved September 4, 2018, from www.census.gov/programs-surveys/acs/data.html

U.S. Census Bureau. (2012). Employment in STEM occupations by field of degree for the first listed bachelor's degree: 2012. Retrieved September 4, 2018, from www.census.gov/data/tables/2012/demo/industry -occupation/college-graduates.html

U.S. Census Bureau. (2014). Census Bureau reports majority of STEM college graduates do not work in STEM occupations. Press release no. CB14-130. Retrieved September 4, 2018, from www.census.gov/newsroom/press -releases/2014/cb14-130.html

Van Wyk, R. J., \& Gaynor, G. (2014). An academic template for graduate programs in engineering and technology management (ETM). Institute of Electrical and Electronics Engineers Engineering Management Review, 42(4), 119-124.

Viergever, R. F., \& Li, K. (2015). Trends in global clinical trial registration: An analysis of numbers of registered clinical trials in different parts of the world from 2004 to 2013. British Medical Journal Open, 5(9), e008932.

Wernick, N. L., Ndung'u, E., Haughton, D., \& Ledley, F. D. (2014). Positioning genomics in biology education: Content mapping of undergraduate biology textbooks. Journal of Microbiology \& Biology Education, 15(2), 268.

Woodin, T., Smith, D., \& Allen, D. (2009). Transforming undergraduate biology education for all students: An action plan for the twenty-first century. CBE-Life Sciences Education, 8(4), 271-273.

Wright, R. L. (2005). Undergraduate biology courses for nonscientists: Toward a lived curriculum. Cell Biology Education, 4, 189-198.

Yanez, M., Khalil, T. M., \& Walsh, S. T. (2010). IAMOT and education: Defining a technology and innovation management (TIM) body-of-knowledge (BoK) for graduate education (TIM BoK). Technovation, 30(7), 389-400. 